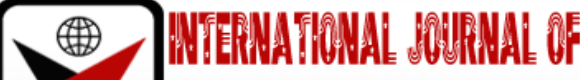

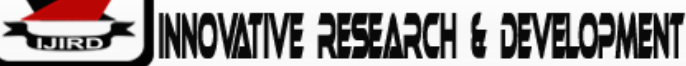

ISSN $2278-0211$ (Online)

\section{Effect of Contextual Teaching - Learning Approach on Students' Achievement in Chemistry in Secondary Schools in Anambra State, Nigeria}

\begin{tabular}{|c|}
\hline Samuel, N.N.C \\
Lecturer, Department Of Science Education, \\
Nnamdi Azikiwe University, Awka, Nigeria \\
Obikizie, Maxwell C. \\
Lecturer, Department Of Science Education, \\
Nnamdi Azikiwe University, Awka, Nigeria \\
\hline
\end{tabular}

\begin{abstract}
:
The study examined the influence of contextual teaching-learning approach (CTLA) on chemistry students' academic attainment in secondary schools in Anambra State, Nigeria using a quasi-experimental design with a sample of 129 students drawn from six education zones in the state. The instrument known as CLCAT validated by two experts with a reliability coefficient of 0.84. Two research questions and two hypotheses guided the study. Mean and standard deviation were used to answer the research questions. The result revealed that CTLA had significant effect on students' academic achievement in chemistry. Finding implies there is need for chemistry teachers to use CTLA in teaching chemistry. Recommendations were made on how chemistry teachers should adopt the use of contextual teachinglearning approach to improve the performance of students in chemistry.
\end{abstract}

Keywords: Science technology, contextual teaching-learning approach, gender, chemistry instruction

\section{Introduction}

Needless to say, for every nation the importance of Science, Technology, Engineering and Mathematics (STEM) is crucial. STEM is one of the ultimate things behind the development of the nation. Proper research and coherent application of STEM can speed up the growth of economy up to a great extent (Okeke, 2008). It is equally important for social, economic and political development. Same thing happens with Nigeria (Ikeobi 2010). STEM has also improved the facilities for water, food, and healthcare delivery. A subject from STEM i.e., Chemistry is very important to solve problems from human interaction with the nature. Despite of the importance of chemistry, students in Nigeria perform poor in chemistry (Ugo \& Akpoghol, 2016). The difference between the developed, developing, and under developed countries however rest on the ability of the developed countries to convert scientific ideas (Ugo \& Akpoghol, 2016).

In recognition of the impact of STEM development to the overall national development, Federal Government of Nigeria has been supporting it through controls, activities and programmes.

Its recognition as core science in Nigerian Education system shows its importance in national development (Ademu, Boris \& Kenni, 2012). Every feature of human endeavour can be featured with the chemistry (Hashimi 2018). Important aspect of scientific concepts can be learned by students through chemistry (Ademu, Boris \& Kenni, 2020).The achievement of students in the subjects is still not encouraging (Ezeliora \& Obikezie 2017). This has raised a matter of concern among the mainstream students of chemical education in Nigeria (Sakiyo \& Badew, 2015). They went further to prove from data collected that between 2008 - 2012, percentages pass of chemistry students in grade A1 - C6 West Africa Senior Secondary School Certificate is 46.30\%. Bello and Oke (2015) supported the claim from the data collected from West African Examination Council Nigeria that the percentage passes of chemistry students in 2013 and 2014 in grades of A1 - C6 are 40.4\% and 45.50\% respectively. Many factors have been attributed as the cause of poor achievement in chemistry especially in West African Senior Secondary School Certificate Examination. Among factors identified were poor methods of teaching and learning, laboratory inadequacy and non-availability of effective teaching and learning resources in classroom (Sakiyo \& Badau, 2015; Bello \& Oke, 2015). The need for new active teaching strategies is more urgent than ever, as the traditional approaches are not very effective with today's students (Osborne \& Dillon, 2008). This was what prompted the present study which tries to find the effect of contextual teaching-learning approach on students' achievement in chemistry in secondary schools in Anambra State.

Contextual Teaching and Learning approach (CTLA) is a conception of teaching and learning that helps teachers relate subject matter content to real world situations and motivates students to make connections between knowledge and its applications to their lives as family members, citizens, and workers. The concept of Contextual Teaching and Learning teaching emphasizes the full student's activity both physically and mentally (Muchtar, 2017). Contextual teaching 
and learning consider that learning is not a memorizing activity, considering facts nor demonstrating repetitious exercise but a process of experience in life naturally. CTLA is a learning concept that helps teachers to connect a subject matter being studied by students to their daily lives so they can feel the meaning from every subject matter being studied and implement it in all aspects of life. Students acquire knowledge and skills from limited context gradually, and from the process of self-construction, so that learning will be meaningful. This CTLA have been used by many educators in Arts and Humanities but science educators and teachers need to use it most to enhance learning in the sciences. Nurhadi (2000) in Satriani, Emilia, Gunawan (2012) has argued that the constructivism philosophy is the reason why teachers choose CTLA as an alternative teaching and learning approach. In this case, the students are expected to learn through 'experiencing' not by 'memorizing' the subject matter. CTLA motivates the learners to take charge of their own learning and to relate between knowledge and its application to the various contexts of their lives. It has a characteristic of relating, experiencing, applying, cooperating, and transferring (REACT) of knowledge learnt (Crawford, 2001). With the numerous benefits of contextual teaching -learning approach, the researchers sought to investigate its effect on the achievement of chemistry students when taught certain chemistry concepts with it.

\subsection{Purpose of this Study}

The purpose of this study are as follows:

- To check whether the contextual teaching- learning method can improve the mean academic achievement of chemistry students.

- To determine if gender can create any difference in the mean academic achievement for chemistry with contextual learning method.

\subsection{Hypotheses}

The following hypotheses were formulated and tested at $95 \%$ confidence interval.

- There is no significant difference in the academic achievement of SS 2 students when taught chemistry concepts with contextual teaching-learning method and a lecture method.

- There is no significant difference caused by gender when students taught chemistry using contextual learning method.

\section{Method}

The design adopted for study was quasi - experimental research design with 759 students. The sample consisted of 129 SS2 chemistry students selected from six educational zones in Anambra State. Purposive sampling technique was used for the selection of one co-educational school from each zone. The criteria being that the school must have presented candidates for West African Senior School Certificate Examination (WASSCE) for at least 3 times. Secondly, the school must have a chemistry teacher with at least 6 years teaching experience. The study covered a period of seven weeks. First week was for familiarizing visit and training of research assistants, second to fourth week was used to teach the chemistry concepts using lecture method which is lecture in the education zone at the end of which 20 objective questions prepared by the researchers from the content taught was administrated to the students as pretest. The fifth to seventh week was used to teach the students the same chemistry concepts using contextual teaching-learning approach after which the same 20 objective question was also administered to the students but this time the questions and options were reshuffled and printed with a different colored paper. The SS 2 chemistry teachers of the six selected co-educational schools served as the research assistants. The teachers were given detailed information and instruction concerning the study. Each used the notes prepared by the researchers to teach in the six weeks. The tests conducted (pre-test and posttest) were marked by the researchers. Five (5) marks were awarded to each question so that 20 questions if correctly answered would have a total of 100 marks. The pretest scores as well as post-test scores had a total of $100 \%$ score. Pre-test scores was recorded as the achievement of the students when taught with lecture method and the post-test scores was recorded as achievement of students when taught with CTLA. Data collected was used for analysis.

\subsection{Instrument}

Based on the WASSEC past question papers a data collection instrument had been designed.

The instrument was titled Contextual-Learning Chemistry Achievement Test (CLCAT). The CLCAT was produced based on the chemistry concepts of Chemical reaction, Halogens, Water and Air. To ensure the reliability of the instrument, the 20 objective questions were administered on a group of 15 students. The result subjected to Cronbach alpha technique to determine the reliability coefficient. A coefficient of 0.84 was obtained, indicating that the instrument was reliable. The data obtained from the pretest and posttest was analyzed using mean, standard deviation and t-test.

\section{Results}

The results are presented in answer to research questions and hypotheses.

- $\quad$ Research question 1: What is the mean academic achievement score of SS 2 students when taught chemistry concepts using contextual teaching -learning approach in Anambra State? 


\begin{tabular}{|c|c|c|c|}
\hline \multicolumn{2}{|c|}{ Gender } & Posttest & Pretest \\
\hline \multirow{3}{*}{ Male } & Mean & 10.6094 & 7.5000 \\
\cline { 2 - 4 } & $\mathrm{N}$ & 64 & 64 \\
\cline { 2 - 4 } & Std. Deviation & 2.75230 & 2.73716 \\
\hline \multirow{3}{*}{ Female } & Mean & 14.5692 & 9.5846 \\
\cline { 2 - 4 } & $\mathrm{N}$ & 65 & 65 \\
\cline { 2 - 4 } & Std. Deviation & 12.70823 & 3.07150 \\
\hline \multirow{3}{*}{ Total } & Mean & 12.6047 & 8.5504 \\
\cline { 2 - 4 } & $\mathrm{N}$ & 129 & 129 \\
\cline { 2 - 4 } & Std. Deviation & 9.40364 & 3.08211 \\
\hline
\end{tabular}

Table 1: Pre-Test and Post-Test Mean Achievement Scores of Students

Table 1: shows that the post-test mean score of students which is (12.6047) is higher than the pre-test mean score (8.5504). This means that CLCAT contextual learning enhanced students' academic achievement in chemistry concepts more than the lecture method with a mean difference of 4.0543. However, the standard deviation showed a wide spread of the scores from the mean among the scores of students taught using contextual teaching and learning approach.

- $\quad$ Research Question 2: What is the difference in pretest and posttest mean academic achievement scores of male and female students taught chemistry using contextual learning method?

\begin{tabular}{|c|c|c|c|c|c|}
\hline & GENDER & N & Mean & Std. Deviation & Std. Error Mean \\
\hline \multirow{3}{*}{ Pretest } & Male & 64 & 7.5000 & 2.73716 & .34215 \\
\cline { 2 - 6 } & FEMALE & 65 & 9.5846 & 3.07150 & .38097 \\
\hline \multirow{2}{*}{ Posttest } & Male & 64 & 10.6094 & 2.75230 & .34404 \\
\cline { 2 - 5 } & FEMALE & 65 & 14.5692 & 12.70823 & 1.57626 \\
\hline
\end{tabular}

Table 2: Pre-Test and Post-Test Mean Achievement Scores of Male and Female Students

Table 2 shows that the mean score of male students is 7.5000 as at against that of female students which is 9.5846 in pretest. In post-test the men score of male students is 10.6094 as against those female students which is 14.5692 . This means that the female students mean achievement scores are higher than that of male students in both pre-test and posttest with a mean score difference of 2.0846 and 3.998 respectively. Looking closely at the standard deviation (SD)of both pretest and posttest for males which are 2.7316 and 2.75230 , there seems not to be much variations or disparity in the academic achievement among the male students even when taught with different methods. Teaching methods effect the male students equally. The female students on the order hand, had 3.07150 and 12.70823 as pretest and posttest standard deviations (SD) respectively. The posttest had a wider variation than the pretest showing that the female students were more effected by CTLA. Some female students improved in their academic achievement more than others hence the wide variations.

- $\mathrm{Ho}_{1}$ : There is no significant difference in the academic achievement of SS 2 students when taught chemistry concept with contextual learning method and those taught in a lecture method.

\begin{tabular}{|c|c|c|c|c|c|c|c|c|c|c|}
\hline & \multicolumn{2}{|c|}{$\begin{array}{c}\text { Levene's Test for } \\
\text { Equality of } \\
\text { Variances }\end{array}$} & \multicolumn{7}{|c|}{ t-test for Equality of Means } \\
\hline & & \multirow[t]{2}{*}{$\Sigma$} & \multirow[t]{2}{*}{ in } & \multirow[t]{2}{*}{-} & \multirow[t]{2}{*}{$\Psi$} & \multirow[t]{2}{*}{ 苞 } & \multirow[t]{2}{*}{ 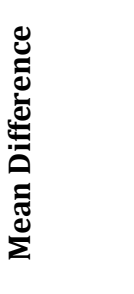 } & \multirow[t]{2}{*}{ 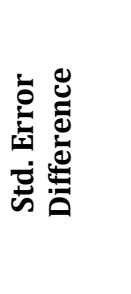 } & \multicolumn{2}{|c|}{ 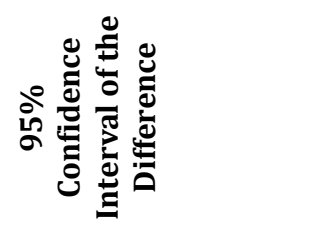 } \\
\hline & & & & & & & & & Lower & Upper \\
\hline \multirow[t]{2}{*}{ Pretest } & $\begin{array}{c}\text { Equal } \\
\text { variances } \\
\text { assumed } \\
\end{array}$ & 2.116 & .148 & -4.067 & 127 & .000 & -2.08462 & .51252 & -3.09880 & -1.07044 \\
\hline & $\begin{array}{c}\text { Equal } \\
\text { variances not } \\
\text { assumed } \\
\end{array}$ & & & -4.071 & 125.762 & .000 & -2.08462 & .51206 & -3.09798 & -1.07125 \\
\hline \multirow[t]{2}{*}{ Posttest } & $\begin{array}{c}\text { Equal } \\
\text { variances } \\
\text { assumed }\end{array}$ & 1.798 & .182 & -2.437 & 127 & .016 & -3.95986 & 1.62489 & -7.17521 & -.74450 \\
\hline & $\begin{array}{c}\text { Equal } \\
\text { variances not } \\
\text { assumed }\end{array}$ & & & -2.454 & 70.081 & .017 & -3.95986 & 1.61337 & -7.17755 & -.74216 \\
\hline
\end{tabular}

Table 3: T-Test Analysis of Pretest and Post-Test Mean Academic Achievement Score of Students 
Table 3 shows that $\mathrm{F}$ scores of pretest and post-test which is 2.116 and 1.795 respectively at 95\% confidence interval. Thus, the null hypothesis is rejected. The mean difference is statistically significant in favor of contextual method.

- $\mathrm{HO}_{2}$ : Gender does not play any significant role academic achievement scores when students taught chemistry using contextual learning method.

\begin{tabular}{|c|c|c|c|c|c|c|c|c|c|c|}
\hline & \multicolumn{2}{|c|}{$\begin{array}{l}\text { Levene's } \\
\text { Test for } \\
\text { Equality of } \\
\text { Variances }\end{array}$} & \multicolumn{7}{|c|}{ t-test for Equality of Means } \\
\hline & & \multirow[t]{2}{*}{ 工 } & \multirow[t]{2}{*}{ 苟 } & \multirow[t]{2}{*}{$\omega$} & \multirow[t]{2}{*}{ 㟔 } & \multirow[t]{2}{*}{ 站 } & \multirow[t]{2}{*}{ 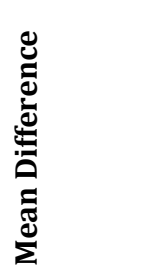 } & \multirow[t]{2}{*}{ 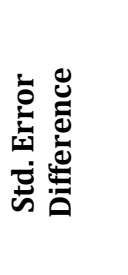 } & \multicolumn{2}{|c|}{ 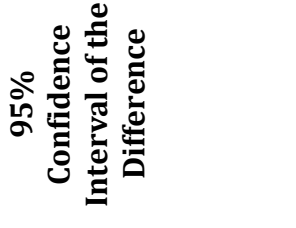 } \\
\hline & & & & & & & & & Lower & Upper \\
\hline \multirow[t]{2}{*}{ ZONE } & $\begin{array}{c}\text { Equal } \\
\text { variances } \\
\text { assumed }\end{array}$ & .073 & .788 & -.353 & 127 & .725 & -.11010 & .31224 & -.72797 & .50778 \\
\hline & $\begin{array}{c}\text { Equal } \\
\text { variances } \\
\text { not } \\
\text { assumed }\end{array}$ & & & -.353 & 126.714 & .725 & -.11010 & .31232 & -.72814 & .50795 \\
\hline
\end{tabular}

Table 4: Independent Samples Test of Male and Female Achievement

Table 4 shows that Gender has no significant difference since it has a 0.725 significance which is bigger than 0.05 , the learning strategy of CTLA affected equally both male and female students.

\section{Discussion}

The result of this study had shown that students achieved better when taught with contextual approach (CTLA) than when taught using lecture method (LM). This could be due to the fact CLCAT (posttest) came after the lecture method of teaching (pretest) there by making the students to perform better due to residual knowledge from lecture method (LM). The result of the study supports the views of previous researchers (Sakiyo \& Badau 2015) and (Bello \&Oke 2015) who indicated that the achievement of students in West African Senior Secondary School Certificate Examination in grade level A - C6 and D7 - F9 may be as a result of teaching method used by the chemistry teachers. Candidates who performed well, may be as a result of residual knowledge they possessed from previous studies in chemistry classroom. The result showed that gender had no significant effect on attainment in chemistry in Anambra State based secondary schools using contextual approach (CTLA).

\section{Conclusion}

The study indicates that use of CTLA able to achieve higher mean achievement scores compare to Lecture Method (LM). CTLA shows good result for consolidation of the knowledge. This study shows that gender does not play any significant role. This method also adds value to the teaching concepts by improving students' understanding level and teachers' instructional strategies for delivering lectures on abstract concepts.

\section{Recommendations}

Based on the findings the following recommendations can be made:

- Chemistry teachers should employ CTLA more in the teaching of chemistry.

- $\quad$ Since residual knowledge from lecture method (LM) may be a factor that enhances the achievement of students in contextual method (CTLA), teachers were advised to use two or more suitable teaching methods for effective academic achievement in chemistry.

- Chemistry teachers should be provided with the facilities such as computers, storages devices and projectors which they need for preparing and teaching their lessons especially when two teaching methods will be used in other to manage time in the classroom.

\section{References}

i. Adanu, A.S., Bons, 0.0 \& Kenni. A.N (2013) Trends in students' achievement in senior school certificate examination (SSCE) in Chemistry between 2008 and 2012. International Journal of Science and research (IJSR), India 2 (6) $363-395$.

ii. Bello, M.A., \& Oke M.G (2015) An appraisal of candidates' achievement in the West African Senior School Certificate Examination (WASSCE) among WAEC member countries. WAEC HQ, Accra and Lagos

iii. Crawford, L. M. (2001). Teaching contextually: Research, rationale, and techniques for improving student motivation and achievement. Texas: CCI Publishing, Inc 
iv. Ezeliora; B.A. \& Obikezie M.C. (2017). The challenges facing chemistry teachers in the utilization of IC Packages in instruction. Journal of science education and allied discipline Vol. 2(1); 51 - 60.

v. Hshimi, MA (2018) Challenges of educational Development in Nigeria; Issue of Chemistry Science, Journal of chemistry and materials Research. Retrieved from http//www.iiste.org on 11 Fed, 2020 at $2.14 \mathrm{pm}$

vi. Ikeobi, I.O (2010) Beyond the Stereotype: Thoughts and reflections on education. Yaba: the CBN press limited.

vii. Muchtar, M. I. (2017). Contextual teaching and learning method in studying Arabic. Hunafa: JurnalStudiaIslamika. 14 (1) $175-188$

viii. Okeke, E.A.C. (2008) clarification and analysis of gender concepts. Focus on research, reproductive health education, and gender sensitive classroom. Journal of the Science Teachers Association of Nigeria and STM series, $2,5-8$.

ix. Sakiyo, J. \& Badau, K.M. (2015) Assessment of the trend of secondary school students' academic performance in the science, mathematics and English. Nigeria Advances in Social Science Research Journal 2 (2) 31 - 37 doi: 10.14738/assrz 22.805.

x. Satriani, I., Emilia, E., \& Gunawan, M. H. (2012). Contextual teaching and learning approach to teaching writing. Indonesian Journal of Applied Linguistics, 2(1) 10-22

xi. Ugo, E. A. \& Akpoghol, T.V (2016) Improving Science, Technology, Engineering and Mathematics (STEM) programs in Secondary Schools in Benue State Nigeria: Challenges and prospects Asia Pacific Journal of education, arts and science 3 (3) $6-16$ 